Egyptian Journal of Aquatic Biology \& Fisheries

Zoology Department, Faculty of Science,

Ain Shams University, Cairo, Egypt.

ISSN $1110-6131$

Vol. 25(3): 85 - 99 (2021)

www.ejabf.journals.ekb.eg

\title{
Impact of carbamide perhydrate on the snail Bulinus truncatus, the intermediate host of Schistosoma haematobium
}

\author{
Hebat-Allah A. S. Dokmak ${ }^{1}$, Mohamed A. EL-Emam ${ }^{1}$, Hanan S. Mossalem ${ }^{1}$, \\ Tarek A. EL-Tayeb ${ }^{3}$ and, Magdy T. Khalil ${ }^{2}$. \\ ${ }^{1}$ Medical Malacology Department, Theodor Bilharz Research Institute, Egypt. \\ ${ }^{2}$ Faculty of Science, Ain Shams University, Cairo, Egypt. \\ ${ }^{3}$ National Institute for Laser Enhanced Science (NILES), Egypt. \\ *Corresponding author: hebas80@yahoo.com
}

\section{ARTICLE INFO}

\section{Article History:}

Received: April 9, 2021

Accepted: April 30, 2021

Online: May 26, 2021

Keywords:

Bulinus truncatus,

molluscicidal,

carbamid perhydrate,

biochemical parameters.

\begin{abstract}
Control of the snail Bulinus truncatus is an essential component in elimination of the parasite Schistosoma haematobium in Egypt. Carbamide perhydrate, as a disinfectant and bleaching agent in cosmetics and pharmacioticals, was bio-assayed against $B$. truncatus snails. It was toxic to these snails with $\mathrm{LC}_{90}$ of $138.54 \mathrm{ppm}$ after 24 -h of exposure. It caused significant detrimental effects on the total protein content, the activities of AST, ALT and ALP enzymes and the levels of steroid sex hormones in the tissues of treated snails, which in turn reflected negatively on their fecundity $(\mathrm{Mx})$ and reproductive rate $\left(\mathrm{R}_{0}\right)$. The reduction rate of $\mathrm{R}_{0}$ for snails treated with $\mathrm{LC}_{25}$ was $76.66 \%$. Moreover, this compound exerted obvious histological changes in the digestive and hermaphrodite glands of treated snails, where secretory and digestive cells in the digestive gland were swelled and ruptured in addition to degeneration of connective tissues, ova and sperms in acini of the hermaphrodite gland. So, carbamide perhydrate exerted harmful effects to B.truncatus snails, as it negatively affected their biological and physiological activities as well their productivity, hence minimize or diminish the snail population available for the transmission of $S$. haematobium. Therefore, this compound could be suggested as an effective and safe component in schistosomiasis control program.
\end{abstract}

\section{INTRODUCTION}

Schistosomiasis is considered a tropical parasitic disease of poverty caused by certain blood flukes of the genus Schistosoma, which induces cerious health problems to infected humans and it is transmitted by specific snail species present in irrigation systems (WHO, 2017). The three major forms of human shistosomiasis are $S$. mansoni, S. haematbium and S. japonicum transmitted by the snail intermediate hosts of the genera Biomphlaria, Bulinus and Oncomelania, respectively (Malek \& Cheng, 1974). The prevalence of schistosomiasis is rapidly increasing with the extension of water development projects (Yapi et al 2005).

The control of this disease is based on large-scale treatment of at-risk population groups, access to safe water, improving sanitation, hygiene education and 
snail control (WHO, 2020). Snail control measures are considered an important component of an integrated program for schistosomiasis elimination (Clennon $\boldsymbol{e t}$ al, 2004). Several methods were used to control the snail intermediate hosts of schistosomiasis (Abd El-Ghany and Abd El-Ghany, 2017). Among them is the chemical molluscicides, but due to their toxicity to the non-target organisms and high costs (WHO, 2014), there is an interest to find out suitable environmentally safe compounds. In this context, the safety of photosensitizers to human beings and aquatic ecosystems is an advantage for evaluating their effect against the snail intermediate hosts of schistosomiasis (Gawish et al, 2009 and Ragheb et al, 2018). The use of photosensitizing dyes for inactivation of pathogenic agents has been evaluated in red and platelet blood components (Wagner and Skripchenko, 2003). Moreover, the flouresence of some anticancer photosensitizers allow their use as tumor localizing agents which are useful in precancerous conditions (Angieszka $\boldsymbol{e t} \boldsymbol{a l}$, 2003). Carbamide perhydrate (urea hydrogen peroxide) is known as antiseptic and disinfectant for a wide range of pharmaciotical applications (Kihn, 2000 and Brunton et $\boldsymbol{a l}, \mathbf{2 0 0 4})$. It is readily biodegradable to urea as fertilizer and hydrogen peroxide which associates to water and active oxygen, as well it characterized by imperceptible risk for plant, animal and human ecosystems (Attin and Hannig, 2004) .

Therefore, carbamide hydrate could be suggested as safe effective agent for controlling the medically important snails. Thus, the present work aimed to assess the molluscicidal properties of carbamide perhydrate against Bulinus truncatus snails, followed by evaluating the effect of sublethal concentrations of this compound on some biochemical aspects, steroid sex hormones and fecundity of these snails. In addition to recording the histological changes in the digestive and hermaphrodite glands of treated snails.

\section{MATERIALS AND METHODS}

\section{. Carbamide perhydrate}

Carbamide perhydrate, was purchased from El-Gomhoryia Company for Chemicals, Cairo, Egypt. The agent is rapid-soluble in water.

\section{Snails}

Laboratory-bred B. truncatus snails used were from Medical Malacology Department, Theodor Bilharz Research Institute (TBRI), Imbaba, Giza, Egypt. They were maintained in dechlorinated water $\left(24 \pm 1^{\circ} \mathrm{C}\right)$ and fed oven-dried lettuce leaves. Water was changed once weekly and dead snails were removed.

\section{Bioassay tests}

A stock solution of $1000 \mathrm{ppm}$ from carbamide perhydrate was prepared. Then Bulinus truncatus snails were exposed to the concentrations 50, 75, 100, 125, and 150 $\mathrm{mg} / \mathrm{L}$ for 24 hours. Thereafter, the snails were thoroughly washed and transferred to 
clean dechlorinated water to recover for $24 \mathrm{~h}$. For each concentration, 3 replicates were used each of 10 snails $(6-8 \mathrm{~mm}) / \mathrm{L}$. Mortality of snails was recorded (WHO 1993) and analyzed to obtain the lethal concentration values $\mathrm{LC}_{50} \& \mathrm{LC}_{90}$ by probit analysis (WHO 1965\&Finney, 1970).

\section{Assessment of carbamide perhydrate on snails' fecundity:}

Three replicates of $B$. truncatus $(6-8 \mathrm{~mm})$, each of 10 snails/L, were used for each of $\mathrm{LC}_{10}$ and $\mathrm{LC}_{25}$ of carbamide perhydrate. Then, the snails were exposed for $24 \mathrm{~h}$ only at the beginning of the experiment to these concentrations. After that, they were transferred to clean dechlorinated water for recovery and observation during the next four consecutive weeks under laboratory conditions. The control snails were kept in clean dechlorinated water throughout the experimental period (4 weeks). The survivorship of snails (Lx) and the number of laid eggs/snails (Mx) were recorded weekly; the reproductive rate $\left(\mathrm{R}_{0}\right)$ was calculated at the end of the experiment. Throughout the experimental period the snails were fed oven-dried lettuce leaves and pieces of foam sheets were used for egg deposition; the water was changed weekly.

\section{Assessment of carbamide perhydrate on snails' biochemical parameters :}

The snails were exposed to $\mathrm{LC}_{50}$ and LC90 of carbamide perhydrate for $24 \mathrm{~h}$. Then, the soft tissues of the survived snails in the treated and control groups were removed from the shells and homogenized $(1 \mathrm{~g} / 2 \mathrm{~mL}$ dechlorinated water) using UP $200 \mathrm{H}$ ultrasonic processor, and the suspensions were centrifuged at 4,000 rpm for $45 \mathrm{~min}$ at $25 \pm 1^{\circ} \mathrm{C}$. Centrifuge $5415 \mathrm{R}$, eppendorf. The pellets were discarded while the supernatant was subjected to estimate the activities of tansaminases enzymes (ALT and AST) using the Reitman and Frankel (1957) technique, alkaline phosphatase (ALP) according to Bessey et al (1946), total protein and albumin were determined according to the method of Doumas (1975) and Gustafsson (1976).

\section{Assessment of carbamide perhydrate on snails' steroid sex hormones:}

Five sets of $B$. truncatus snails, each of 3 replicates (10 snails/ L each) were used. The $1^{\text {st }}$ set was control. The other sets were exposed to carbamide perhydrate concentrations, $\mathrm{LC}_{25}\left(2^{\text {nd }}\right.$ and $3^{\text {rd }}$ sets $)$ and $\mathrm{LC}_{50}\left(4^{\text {th }}\right.$ and $5^{\text {th }}$ sets $)$ for 24 hours. Then, the levels of steroid sex hormones were determined in the $2^{\text {nd }}$ and $4^{\text {th }}$ sets after keeping the snails for 24 hours of recovery. Meanwhile, in the $3^{\text {rd }}$ and $5^{\text {th }}$ sets the hormone levels were determined directly after snails exposure to carbamide perhydrate without recovery.

For hormones determination, the soft tissues of survived snails in treated and control sets were removed from the shell and homogenized $(1 \mathrm{~g} / 2 \mathrm{ml}$ dechlorinated water ) using UP $200 \mathrm{H}$ ultrasonic processor, and the suspensions were centrifuged at $4000 \mathrm{rpm}$ for 45 minutes at $25 \pm 1^{0} \mathrm{C}$. Centrifuge $5415 \mathrm{R}$, eppendorf. The pellets were discarded, while the aliquots of supernatants were subjected to ELISA runs for estimation of the levels of testosterone (DRG Instruments, Gmbh, Germany Cat., EIA- 1559), progesterone (DRG Instruments, Gmbh, Germany Cat., EIA-1561) and 
estradiol ( Diagnostics Biochem Canada Inc," DBC"; Cat., CAN-E-430). The absorbance of the calebrators, controls and the test samples was measured using ELISA reader, stat fax, device, USA. OK the antibodies specific kit for humans; due to their is not found specific antibodies kit for snails and all authors in our field, malacology are using the specific antibodies kit for humans.

\section{Assessment of carbamide perhydrate on histological features of the snails' hermaphrodite and digestive glands:}

The snails were treated with $\mathrm{LC}_{50} \& \mathrm{LC}_{90}$ of carbamide perhydrate as mentioned before; three replicates (10 snails/L each) were used for each of control and the tested groups. Thereafter, the snail's hermaphrodite and digestive gland were dissected out of their shells and were fixed using Bouin's fixative, then embedded in wax blocks, sectioned $(5-8 \mu \mathrm{m})$, and stained with delafied-haematoxyline and eosin (EL-Nahas and EL-Deeb, 2007).

\section{Statistical analyses}

Statistical analyses were run on IBM compatible PC using SPSS for windows statistical package (SPSS, 2006). Lethal concentrations were calculated using probit analysis. The mortality rates of experimentalgroups were compared using Pearson's Chi-square test. Values of biochemical parameters were expressed as mean \pm SD. Student's t-test was applied to locate significant changes in between control and treated groups (Sokal and Rohlf, 1995).

\section{RESULTS}

Table (1) indicates that carbamide perhydrate exhibited a considerable toxic effect against $B$. truncatus snails. Thus, its $\mathrm{LC}_{90}$ was $138.54 \mathrm{ppm}$ after $24 \mathrm{~h}$ exposure and the slope value showed the lethal concentration probability line to be steep which means sensitivity of these snails to this compound is concentration dependent.

Table (1): Molluscicidal activity of carbamide perhydrate against Bulinus truncatus snails ( $24 \mathrm{~h}$ exposure).

\begin{tabular}{cccccc}
\hline $\begin{array}{l}\mathrm{LC}_{10} \\
\mathrm{ppm}\end{array}$ & $\begin{array}{c}\mathrm{LC}_{25} \\
\mathrm{ppm}\end{array}$ & $\begin{array}{c}\mathrm{LC}_{50} \\
\mathrm{ppm}\end{array}$ & $\begin{array}{c}\text { Confidence limits } \\
\text { of } \mathrm{LC}_{50} \\
\mathrm{ppm}\end{array}$ & $\begin{array}{c}\mathrm{LC}_{90} \\
\mathrm{ppm}\end{array}$ & slope \\
\hline 44.92 & 67.09 & 91.73 & $73.34-107.83$ & 138.54 & 1.65 \\
\hline
\end{tabular}

For snail control strategies, maintaining a low reproductive rate is of critical importance. Reducing of snails' egg laying capacity is an effective measure of reproductive control. The present data (Table 2) demonstrate that carbamide perhydrate has deleterious long lasting effect on survivorship (Lx) of B. truncatus snails during the experimental recovery period. Thus, snail groups exposed to $\mathrm{LC}_{10}$ 
and $\mathrm{LC}_{25}$ suffered from sharp decrease in this parameter (Lx) during the experimental period (4 weeks). The recorded Lx value for these snail groups was 0.2 (20\% survival rate) at the $3^{\text {rd }}$ and $2^{\text {nd }}$ weeks, respectively, compared to 0.8 (80\% survival rate) for control group. Regarding the fecundity $(\mathrm{Mx})$ of snails, the maximum number of eggs laid by snails treated with $\mathrm{LC}_{10}$ and $\mathrm{LC}_{25}$ of carbamide perhydrate was 25.0 and 10.4 eggs/snail at the $2^{\text {nd }}$ and $1^{\text {st }}$ weeks, respectively, compared to 26.0 eggs/ control snails at the $2^{\text {nd }}$ week. However, the overall number of eggs laid by each of the treated snail group was less than that of control group.

Table (2): survivorship (Lx) and fecundity (Mx) of Bulinus truncatus snails exposed to carbamide perhydrate.

\begin{tabular}{|c|c|c|c|c|c|c|c|c|c|}
\hline \multirow{2}{*}{$\begin{array}{l}\text { Observation } \\
\text { Period } \\
\text { (week) }\end{array}$} & \multicolumn{3}{|c|}{ Control } & \multicolumn{3}{|c|}{ LC10ppm } & \multicolumn{3}{|c|}{ LC25 ppm } \\
\hline & $\mathrm{Lx}$ & $\mathrm{Mx}$ & $\mathrm{Lx} \mathrm{Mx}$ & $\mathrm{Lx}$ & $\mathrm{Mx}$ & $\mathrm{Lx} \mathrm{Mx}$ & $\mathrm{Lx}$ & $\mathrm{Mx}$ & $\mathrm{Lx} \mathrm{Mx}$ \\
\hline 0 & 1.00 & 6.24 & 6.24 & 1.00 & 6.24 & 6.24 & 1.00 & 6.24 & 6.24 \\
\hline 1 & 0.80 & 10.57 & 8.46 & 1.00 & 1.00 & 1.00 & 0.40 & 10.40 & 4.16 \\
\hline 2 & 0.80 & 26.00 & 20.80 & 0.80 & 25.00 & 20.00 & 0.20 & 0.00 & 0.00 \\
\hline 3 & 0.80 & 8.33 & 6.66 & 0.20 & 4.50 & 0.90 & 0.00 & 0.00 & 0.00 \\
\hline 4 & 0.40 & 6.00 & 2.40 & 0.00 & 0.00 & 0.00 & 0.00 & 0.00 & 0.00 \\
\hline Ro & & & 44.56 & & & 28.14 & & & 10.40 \\
\hline Reduction \% & & & & & & 36.85 & & & 76.66 \\
\hline
\end{tabular}

For the snails' reproductive rate $\left(\mathrm{R}_{0}\right)$ it was negatively affected by their exposure to $\mathrm{LC}_{10}$ and $\mathrm{LC}_{25}$ of carbamide perhydrate. The values of $\mathrm{R}_{0}$ for treated snails were less than that of control group by $36.85 \%$ and $76.66 \%$, respectively (Fig 1).

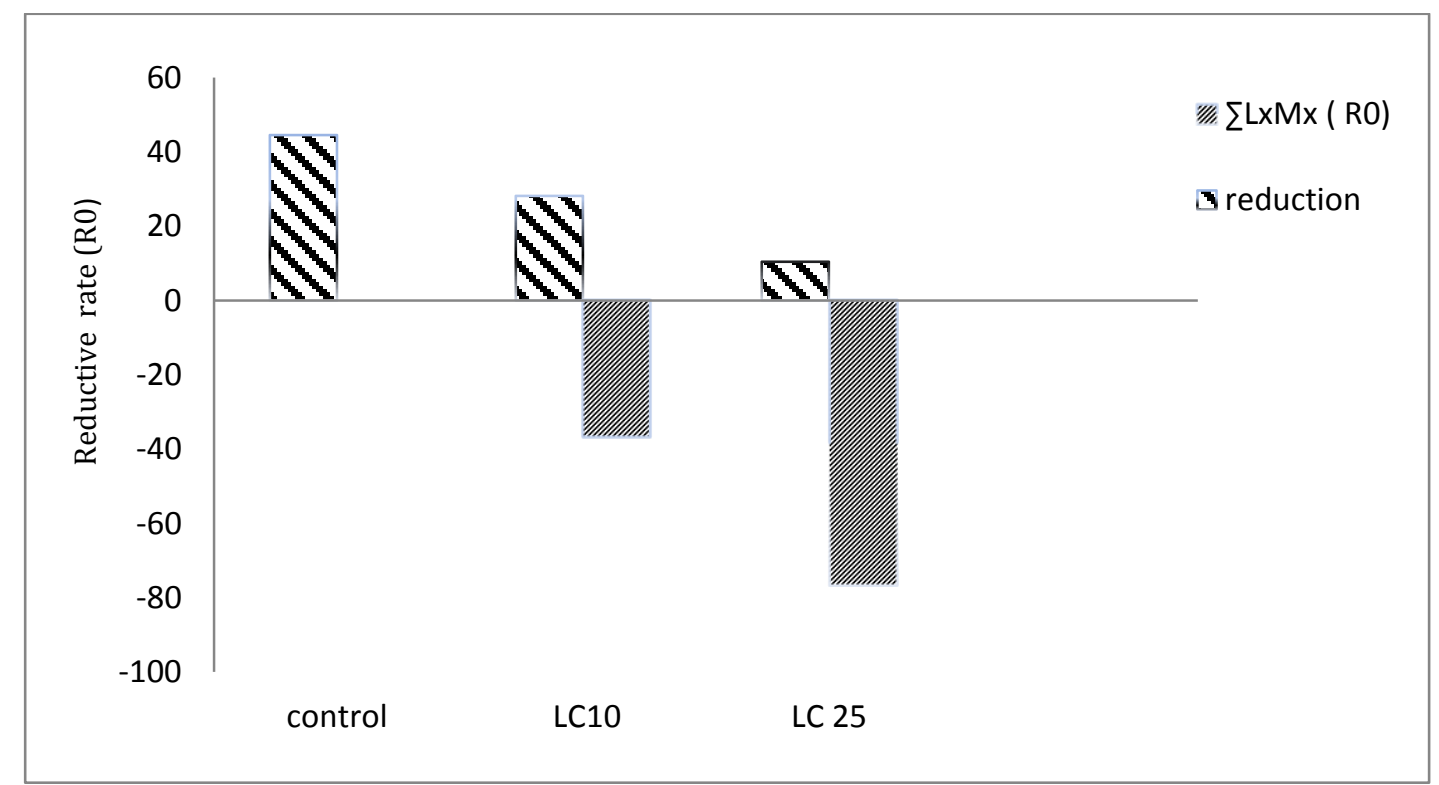

Fig (1): Reproductive rate $\left(\mathrm{R}_{0}\right)$ of Bulinus truncatus snails exposed to carbamide perhydrate . 
The enzymes AST, ALT and ALP (Table 3) are important enzymes implicated in several physiological and pathological processes and cover diverse biological functions. It is clear that treatment of snails with $\mathrm{LC}_{50}$ carbamide perhydrate significantly increased the activities of these enzymes $(\mathrm{p}<0.01)$. The high increase in the activities of these enzymes for snails exposed to $\mathrm{LC}_{90}$ was 2.5, 5.59 and 11.8 folds in comparison with those of control group. On the other hand, table (3) revealed a significant decreament in the total protein, albumin and globulin contents in tissues of snails treated with $\mathrm{LC}_{50}$ and $\mathrm{LC}_{90}$ carbamide perhydrate compared to control group ( $\mathrm{p}<0.01$ ). The total protein level for snails treated with $\mathrm{LC}_{90}$ was $6.99 \mathrm{mg} / \mathrm{g}$ tissue compared to $44.3 \mathrm{mg} / \mathrm{g}$ tissue for control group (84.2\% reduction).

Table (3): Effect of carbamide perhydrate on biochemical parameters in the tissues of Bulinus truncatus snails.

\begin{tabular}{|c|c|c|c|c|c|c|}
\hline Treatment & $\begin{array}{l}\text { AST U/g/ } \\
\text { tissule }\end{array}$ & $\begin{array}{l}\text { ALTU/g } \\
\text { tissue }\end{array}$ & $\begin{array}{l}\text { ALP U/g } \\
\text { tissue }\end{array}$ & $\begin{array}{l}\text { Total Protein mg/g } \\
\text { tissue }\end{array}$ & $\begin{array}{l}\text { Albumin } m g / g \\
\text { tissue }\end{array}$ & $\begin{array}{l}\text { Globulin mg/g } \\
\text { tissue }\end{array}$ \\
\hline Control & $19.32 \pm 0.79$ & $10.26 \pm 0.26$ & $4.7 \pm 0.27$ & $44,3+0,1$ & $14,8 \pm 0,05$ & $29.5 \pm 0.06$ \\
\hline Carbamide perhydrate $\mathrm{IC}_{50}$ & $41,62 \pm 0.27^{7 *}$ & $62.5 \pm 0.27^{* *}$ & $52.47 \pm 0.08^{* *}$ & $6.89 \pm 0.05^{* *}$ & $5.26 \pm 0.07^{* *}$ & $1.63 \pm 0.07^{* *}$ \\
\hline Carbamide perhydrate $\mathrm{LC}_{90}$ & $43.54 \pm 0.30^{* *}$ & $67.6 \pm 0.27^{* *}$ & $55.46 \pm 0.22^{* *}$ & $6.99 \pm 0.07^{* *}$ & $5.22 \pm 0.08^{* *}$ & $1.77 \pm 0.07^{* *}$ \\
\hline
\end{tabular}

For determination of steroid sex hormones in tissue homogenate of $B$. truncatus snails, 5 groups ( 20 snails each) were used. One as control group, the others were exposed to $\mathrm{LC}_{25}$ (2 groups) and to $\mathrm{LC}_{50}$ (2 groups) for 24 hours. Thereafter, one group of each concentration was subjected directly for hormones determination, meanwhile, the others were left for 24 hours recovery before determination of hormones.

Table (4) reveals decrement in levels of steroid sex hormones in tissue homogenate of snails treated with carbamide perhydrate. The concentration of testosterone for snails exposed to $\mathrm{LC}_{50}$ without recovery was $7.8 \mathrm{ng} / \mathrm{ml}$ compared to $9.2 \mathrm{ng} / \mathrm{ml}$ for control group ( $\mathrm{p}<0.05$ ). Similar observation was recorded for $17 \beta$-estradiol in snails treated with carbamide perhydrate then left for 24 hours of recovery. In this case, the level of this hormone for snails exposed to $\mathrm{LC}_{50}$ was $219.5 \mathrm{pg} / \mathrm{ml}$ compared to $257.3 \mathrm{pg} / \mathrm{ml}$ for control group ( $\mathrm{p}<0.01$ ). However, elevations of this hormone in snails treated with $\mathrm{LC}_{25}$ were not significantly different from control group. For progesterone, its concentrations in snails exposed to $\mathrm{LC}_{25}$ and $\mathrm{LC}_{50}$ were significantly less than that of control group. The level of this hormone for snails exposed to $\mathrm{LC}_{50}$ followed by 24 hours of recovery was $4.7 \mathrm{ng} / \mathrm{dl}$ compared to $10.5 \mathrm{ng} / \mathrm{dl}$ for control group $(\mathrm{p}<0.01)$.

Concerning the histological changes, the digestive gland transverse sections of snails treated with $\mathrm{LC}_{50}$ and $\mathrm{LC}_{90}$ of carbamide perhydrate (Fig 2, A-C) showed rupture and swelling of digestive cells compared to control snails that showed normal digestive and secretory cells. Moreover, the hermaphrodite gland transverse sections 
of snails treated with the same concentrations of carbamide perhydrate (Fig 2, D-F) revealed varying degrees of degenerations, atrophy and rupture of different cell types, ova and sperms of the glands' acini. Furthermore, the most prominent damages were clear for several vacuolated ova, degeneration and scattered sperms, as well as degeneration of the acinus' germinal epithelial layer that lead to ceasing snails' oviposition for some weeks during the experimental period.

Table (4): Effect of Carbamide perhydrate on steroid sex hormones in tissues of Bulinus truncatus snails (Mean \pm S.D.).

\begin{tabular}{|c|c|c|c|}
\hline Treatment & $\begin{array}{c}\text { Progesterone } \\
\mathrm{ng} / \mathrm{dl}\end{array}$ & $\begin{array}{c}\text { Testosterone } \\
\mathrm{ng} / \mathrm{ml}\end{array}$ & $\begin{array}{c}17 \beta \text {-estradiol } \\
\mathrm{pg} / \mathrm{ml}\end{array}$ \\
\hline Control & $10.5 \pm 0.08$ & $9.2 \pm 0.05$ & $257.3 \pm 0.5$ \\
\hline $\begin{array}{c}\text { LC25 } \\
\text { Exposure, } 24 \mathrm{~h} \\
\text { Recovery }\end{array}$ & $\begin{array}{c}6.8 \pm 1.5 \\
* *\end{array}$ & $8.8 \pm 0.01$ & $262.6 \pm 0.6$ \\
\hline $\begin{array}{l}\text { LC25 } \\
\text { Exposure, without } \\
\text { Recovery }\end{array}$ & $\begin{array}{c}7.9 \pm 1.1 \\
* *\end{array}$ & $\begin{array}{c}8.2 \pm 0.8 \\
*\end{array}$ & $263.5 \pm 0.5$ \\
\hline $\begin{array}{l}\text { LC50 } \\
\text { Exposure, } 24 \mathrm{~h} \\
\text { Recovery }\end{array}$ & $\begin{array}{c}4.7 \pm 2.3 \\
* *\end{array}$ & $\begin{aligned} 7.5 & \pm 1.4 \\
& *\end{aligned}$ & $\begin{array}{c}219.5 \pm 15.8 \\
* *\end{array}$ \\
\hline $\begin{array}{l}\text { LC50 } \\
\text { Exposure, without } \\
\text { Recovery }\end{array}$ & $\begin{array}{c}5.6 \pm 2.1 \\
* *\end{array}$ & $\begin{array}{c}7.8 \pm 0.9 \\
*\end{array}$ & $\begin{array}{c}235.7 \pm 11.2 \\
* *\end{array}$ \\
\hline
\end{tabular}




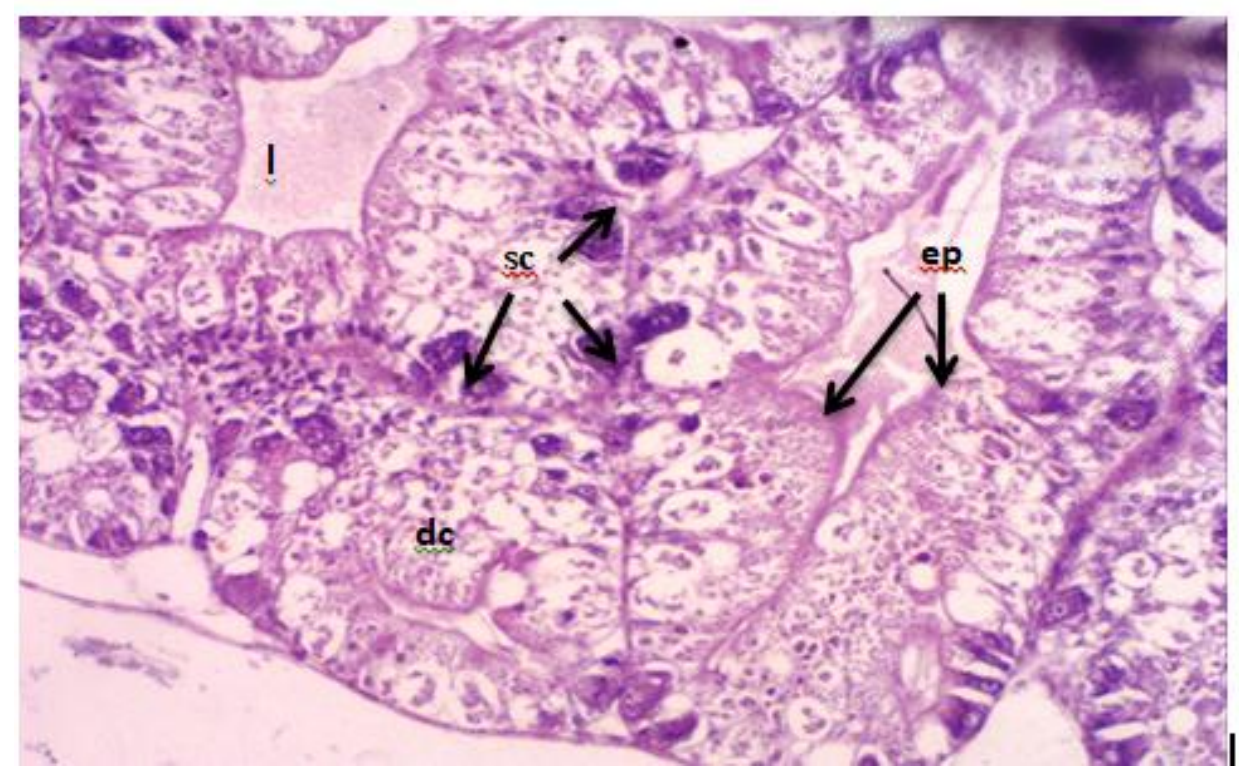

Fig (2) A- Light photomicrograph of transverse section in the digestive gland of Bulinus truncatus (control) stained with E\&H. (x400) showing: normal digestive cells (dc),normal secretory cells (sc),lumen (l) and epithelial layer (ep).

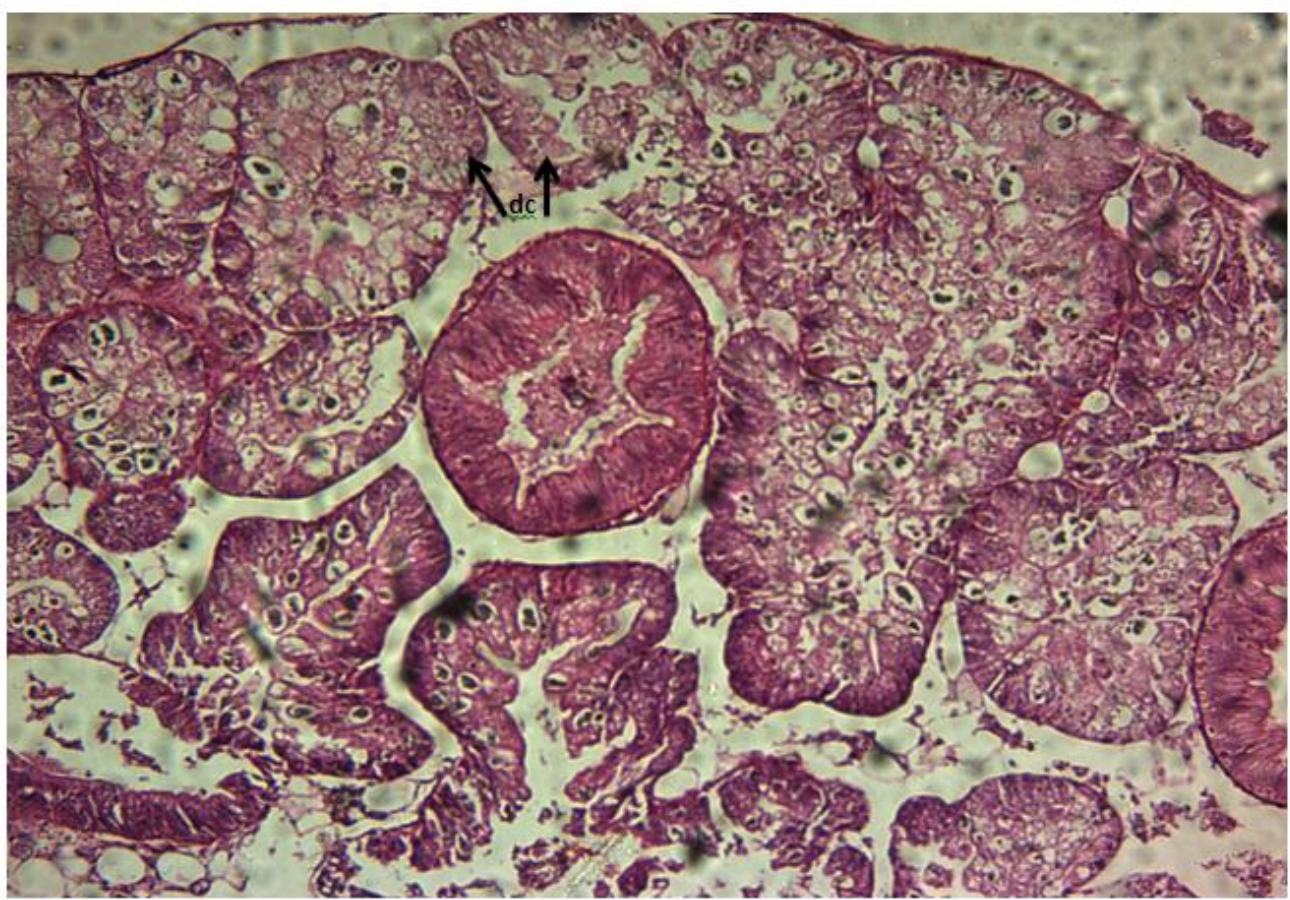

Fig (2) B- Light photomicrograph of digestive gland transverse section of Bulinus truncatus snails treated $\mathrm{LC}_{50}$ of carbamide perhydrate stained with $\mathrm{E} \& \mathrm{H}(\mathrm{x400})$ showing: shranking, swelling and rupture in digestive cells (dc). 


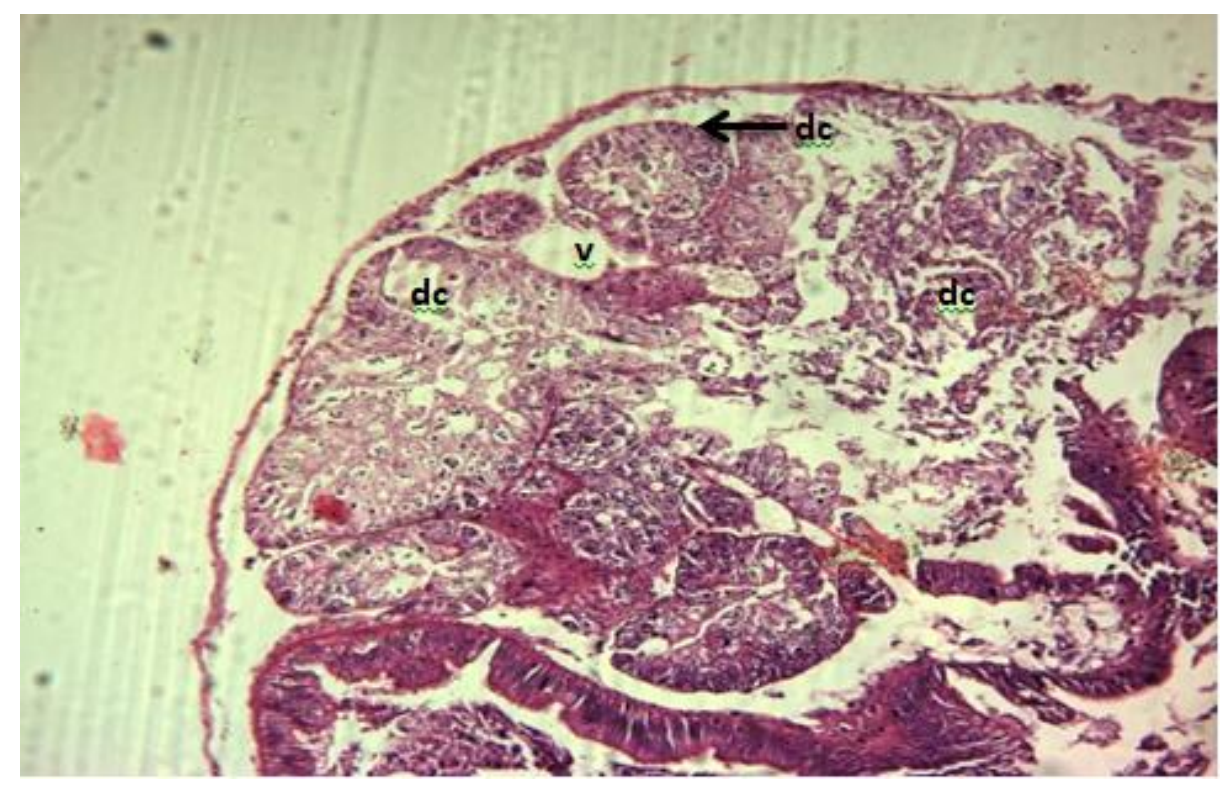

Fig (2) C- Light photomicrograph of digestive gland transverse section of Bulinus truncatus snails treated $\mathrm{LC}_{90}$ of carbamide perhydrate stained with $\mathrm{E} \& \mathrm{H}(\mathrm{x} 400)$ showing: sever shranking with vacuoles $(v)$ and rupture in digestive cells (dc).

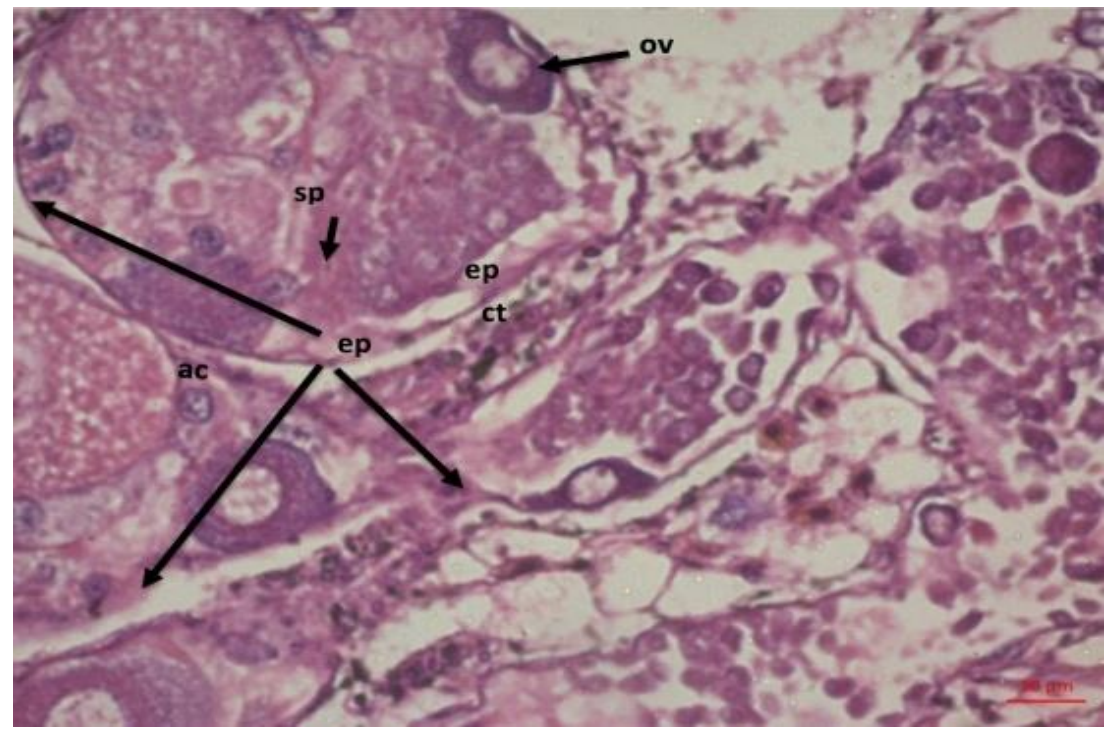

Fig (2) D- Light photomicrograph of transverse section in the hermaphrodite gland of Bulinus truncatus (control) stained with $\mathrm{E} \& H,(\mathrm{x} 400)$. Showing: $\mathrm{Ov}=$ mature ova, $\mathrm{Sp}=$ developed sperms, $\mathrm{Ac}=$ compact acini, $\mathrm{Ct}=$ connective tissue, $\mathrm{Ep}=$ epithelial cells. 


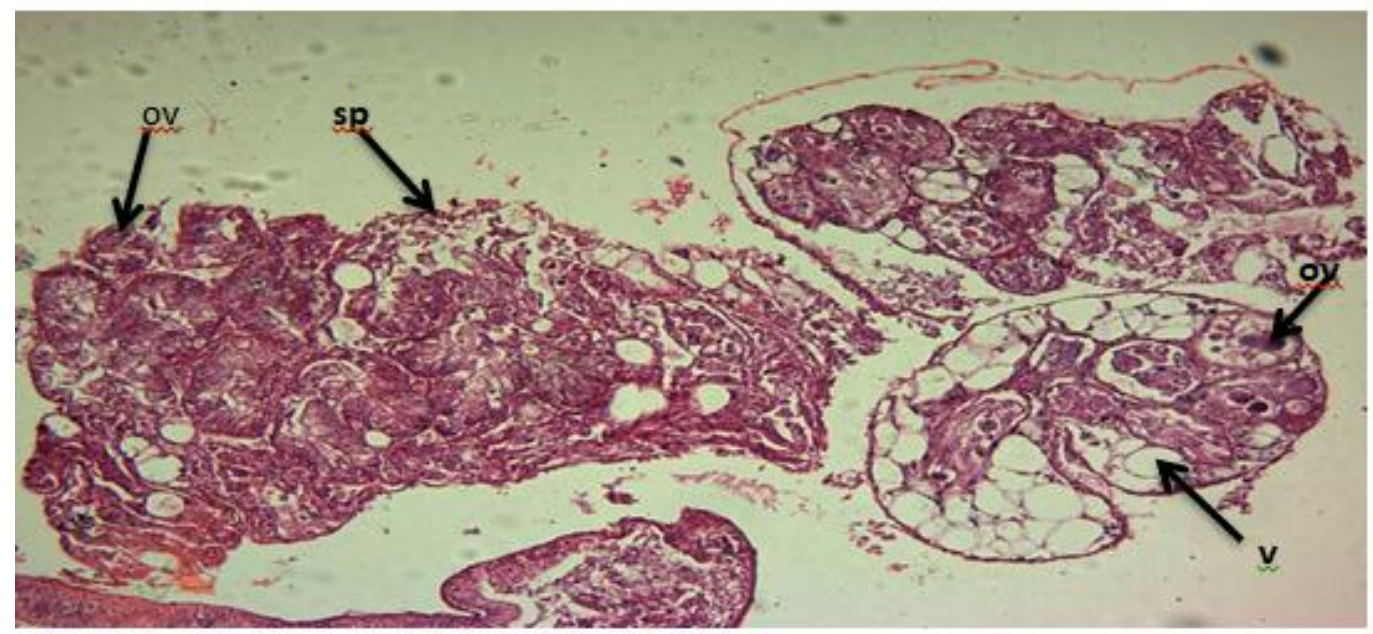

Fig (2) E- Light photomicrograph of transverse section in the hermaphrodite gland of Bulinus truncatus treated with $\mathrm{LC}_{50}$ of carbamide perhydrate stained with $\mathrm{E} \& \mathrm{H}$, (x400). Showing: degenerated ova (ov) ,atrophy and degenerated sperms (sp) and vacuolated ova $(v)$.

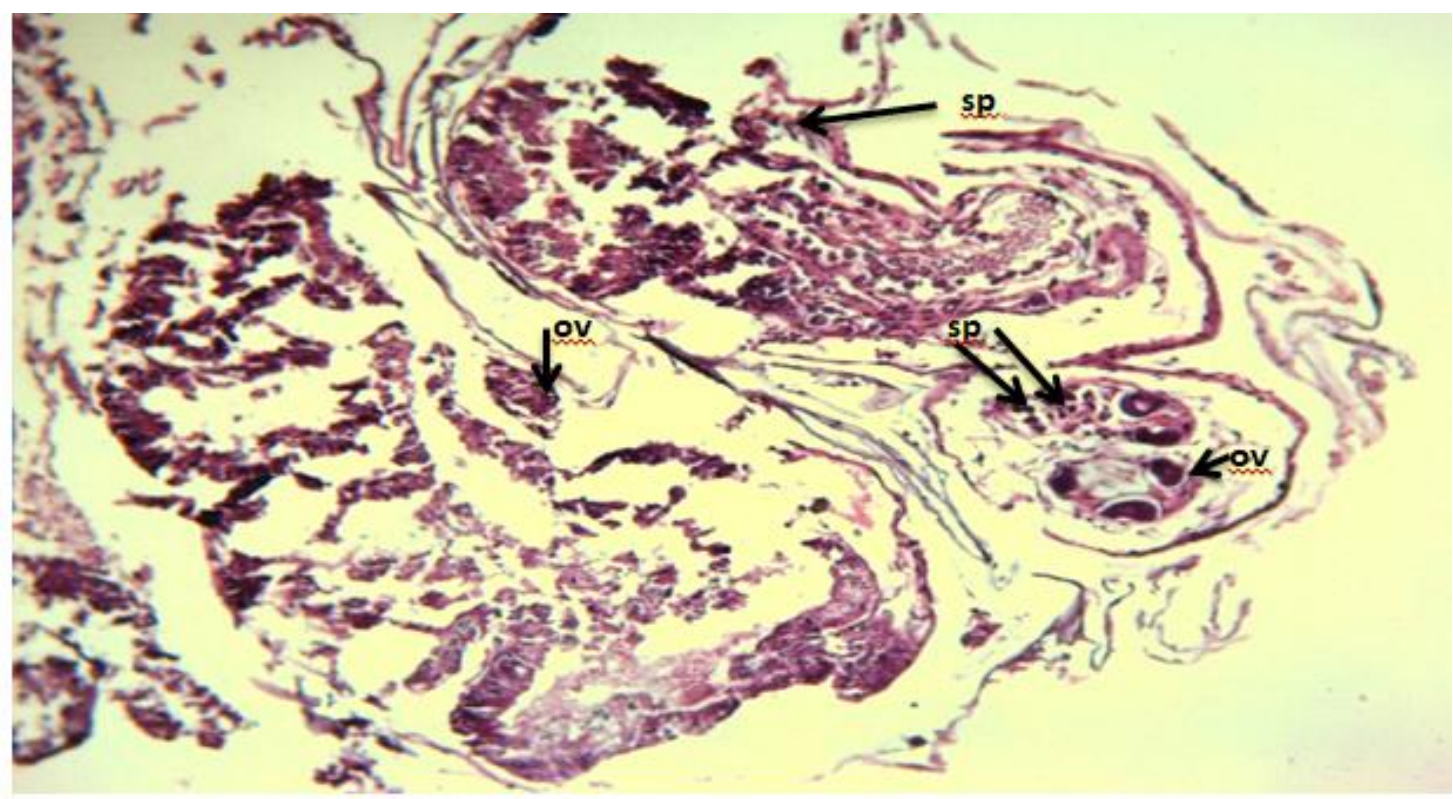

Fig (2) F- Light photomicrograph of transverse section in the hermaphrodite gland of Bulinus truncatus treated with $\mathrm{LC}_{90}$ of carbamide perhydrate stained with $\mathrm{E} \& \mathrm{H},(\mathrm{x} 400)$ showing: sever degenerated ova (Ov),atrophy and degenerated sperms (sp) 


\section{DISCUSSION}

Schistosomiasis infects nearly 250 million people in developing countries, mostly in Asia, Africa and South America. Chemotherapy is considered an essential method for schistosomiasis control, however, there is an interest for developing more efficient molluscicides to control the snail intermediate hosts of this parasite (WHO 2017).

The present toxicity of carbamide perhydrate to $B$. truncatus snails agrees with the data of Gawish et al (2009) on its toxicity to B. alexandrina snails. This could be due to that during the snails exposure to carbamide perhydrate no escape and/or avoidance behaviors of these snails were observed. Such as crawling out, water-leaving and aggregation at the water-air interface hinder the action of molluscicide and eventually increase the snails chance of survival ( Sarquis et al, 1997).

A marked reduction in the survivorship ( $\mathrm{Lx}$ ) of $B$. truncatus snails after treatment with carbamide perhydrate and 4 weeks of recovery was time and concentration dependent (Table 2). Similar results were noticed for B. alexandrina after exposure to carbamide perhydrate (Gawish $\boldsymbol{e t}$ al 2009) and after maintaining with copper and magnesium chlorophyllin (Ragheb et al, 2018 \& Ibrahim and Bakry, 2019).

The fecundity $(\mathrm{Mx})$ and reproductive rate $\left(\mathrm{R}_{0}\right)$ of $B$. truncatus snail groups treated with carbamide perhydrate and recovered for 4 weeks were significantly less than those of control group. This could be partially due to interruption of the snails physiological activities and histological damages in their tissues which were confirmed by the deteriorations caused by the tested compound on total protein levels and in the activities of enzymes AST, ALT and ALP as well as in the levels of steroid sex hormones that in turn my decrease or cease snails'egg-laying capacity (Mx) and decrease the net reproductive rate $\left(\mathrm{R}_{0}\right)$. These findings could be due to the oxidative stresses of hydrogen peroxide and reactive oxygen that arise during hydrolysis of carbamide perhydrate. These oxidative stresses might oxidize the cells macromolecules such as lipids, nucleic acids and protein depending on its intracellular site of formation and promoted detrimental process such as lipid peroxidation, membrane damage that allows the discharge of enzymes, disturbance in their levels and consequently cell death (Stefan \& $\operatorname{Rex} \mathbf{1 9 9 8}$ ).

Recently, Wang et al. (2018) reported that novel compound pyridylphenylureas exhibited strong molluscicidal activity against adult Biomphalaria straminea snails, intermediate host of Schistosoma mansoni and potent inhibitory effects on snail eggs hatchability. Enhancement of the enzymes AST, ALT and ALP, as biomarkers, may provide more information on the molluscicide induced stress on molluscs. The present deteriorations in the activities of these enzymes in tissues of B. truncatus snails treated with carbamide perhydrate may be due to the destructive stress of such compounds on hepatic tissues and/or the snails trials to restore the amino acid balance in their body organs. This conclusion was previously recorded by EL-Emam and Ebeid (1989) on B. alexandrina snails treated with mollotox. Moreover, the photosensitizing dyes, e.g. carbamide perhydrate, could bind 
to plasma membrane where it causes damage with high efficiency on plasma membrane function leading to diffusion of enzymes to the circulation (Irene $\boldsymbol{e t} \boldsymbol{a l}$, 1994). Additionally, the activities of AST and ALT were altered in hemolymph and tissues of Helisoma duryi and Lynenaea natalensis snails by low concentrations of copper, therefore they could be used as biomarker for water pollution (Masola $\boldsymbol{e t} \boldsymbol{a l}$, 2003).

The total protein concentrations in tissues of $B$. truncatus snails treated with the tested mollscicidal compound $\left(\mathrm{LC}_{50} \& \mathrm{LC}_{90}\right)$ were significantly reduced compared to control group. These results were confirmed by previous studies which declared that these changes may be due to disturbances in the function of internal organs of treated snails to compensate and overcome the toxic stress of such compounds, this phenomenon requires high energy that may stimulate protein catabolism (Morad 2005 \& Hasheesh et al, 2011).

Also, the decrease in albumin and globulin levels in Bulinus truncatus snails' tissues may be explained as physiological adaptability of the animal to compensate the toxic stress of carbamide perhydrate or due to its effect on liver parenchyma (Mohamed et al., 2012).

The treatment of snails with carbamide perhydrate showed great histological changes in their digestive and hermaphrodite glands. Snails treatment with $\mathrm{LC}_{50} \&$ $\mathrm{LC}_{90}$ caused swelling and rupturing in digestive cells comparing with control snails that showed normal digestive and secretory cells. Adewunmi \& Ogbe (1986) declared that the overall appearance of the tissues of Bulinus globosus, B. glabrata and Physa watterlotti exposed to methalonic extract of Tetrapleura tetraptera was the swelling of the epithelial cells with disruption of the epithelial lining. They attributed this condition to the accumulation of fluid in these tissue cells suggesting that the molluscicide may either have acted on the membranes of these cells in some way as to alter their permeability or interfered with the regulatory or metabolic processes within them.

The hermaphrodite gland in treated snails showed degeneration in acini cells and mature ova, in addition to atrophy and degeneration in sperms comparing with control group that represented normal structure. This could be interpreting on the basis that the genital organs of treated snails may be high sensitive to such moullscicidal treatment agent than the other vital snail's organs which could lead to their death.

The previous data revealed toxicity of carbamide perhydrate to B. truncatus snails after 24- $\mathrm{h}$ of exposure. Moreover, sublethal concentrations of this compound exhibited severe detrimental effects to the activities of aminotransferases, phosphatases and sex hormones in snails' tissues and histological feature of cells in tissues of the snails' gonads. This negatively reflected on significant decreament of snails reproductive rate and stop their egg-laying, hence minimize or diminish the snails population available for schistosomiasis transmission. Therefore, carbamide perhydrate should be considered as a novel compound in schistosomiasis control program. 


\section{REFERENCES}

AbdEl-Ghany AMA and Abd El-Ghany NMA (2017). Molluscicidal activity of Bacillus thuringiensis strains against Biomphalaria alexandrina snails. Journal of Basic and Applied Sciences., (6): 391-393.

Adewunmi, C.O. and Ogbe, M.G. (1986). The higtopathology of Tetraptleura extract on some fresh water snails. Fitoterapiam., 57(5): 371-374.

Attin, T.; Hannig,C.; Wiegand,A. and Attin,R. (2004). Effect of bleaching on restorative materials and restorations- a systematic review. Dental Materials., 20: 857-861.

Bessey, W.A.; Lowry, O.H. and Brock, M.J. (1946). A method for the rapid determination of alkaline phosphatase with five cubic millimeters of serum. J. Biol. Chem., 164: 321-329.

Brunton, P.A.; Ellwood, R. and Davies, R.A. (2004). A six-month study of two selfapplied tooth whitening products containing carbamide peroxide. Oper. Dent., 29: 623-626.

Clennon, J.A.; King, C.H.; Muchiri, E.M.; Kariuki, H.C.; Ouma, J.H.;Mungai,P. and Kitron,U. (2004). Spatial patterns of urinary schistosomiasis infection in highly endemic areas of costal Kenya. Amr. J. Trop. Med. Hyg., 70: 10291039.

Doumas, B.T. (1975). Standards for total serum protein assays: a collaborative study. Clin.Chem., 21:1159-1166.

El-Emam, M. A. and Ebied, F.A. (1989). Effect of Schistosoma mansoni infection, starvation and molluscicides on acid phosphate, transaminases and total protein in tissues and hemolymph of Biomphalaria alexandrina. J. Egypt. Soc. Parasitol., 19: 139-147.

El-Nahas,H. A. and EL-Deeb, F. A. (2007). Moulluscicidal potency of Pittosporum tobira vearigatum and Hedera canariensis plants against adult Biomphalaria alexandrina snails. Egypt Aquat. Boil.\& Fish., 11 (1):151-170.

Finney, D.J. (1970). Probit analysis (3rdedn.) Combrige University Press.

Gawish, F. A.; El-Sherbini, S.A. and Aly, H. F.(2009). Effect of photosensitization process of carbamide perhydrate on Biomphalaria alexandrina snails and their infection with Schistosoma mansoni. Journal of Applied Sciences Research., 5(1): 46-56.

Gustafsson, J. (1976). Improved specificity of serum albumin determination and estimation of "acute phase reactants" by use of the bromcresol green reaction. Clin. Chem., 22:616-622.

Hasheesh,W.S.; Mohamed, R.T. and Abd EL-Monem, S.( 2011): Biological and physiological parameters of Bulinus truncatus snails exposed to methanol extract of the plant Sesbania sesban. Advances in Biol.Chem., 1:65-73. 
Ibrahim, A.M. and Bakry, F.A. (2019). Assessment of the molluscicidal impact of extracted chlorophyllin on some biochemical parameters in the nervous tissue and histological changes in Biomphalaria alexandrina and Lymnaea natalensis snails. Invertebrate Neuroscience., 19:1-7.

Irene, K.E. ;Joseph, B. and Wei, L.C. (1994). Enfluence of dye and protein location on photosensitization of the plasma membrane. Biochmica. Biophysica. Acta., 1196pp.

Kihn, P.W. (2000). A clinical evaluation of carbamide peroxide and hydrogen peroxide whitening agents during daytime use. J. Am. Dent. Assoc., 131: 1478-1484.

Malek,E.A. and Cheng,T.C. (1974). Snail hosts of human-infecting trematodes. In: Medical and economic malacology.edt. by Emile A. Malek and Thomas C. Cheng, Academic press, New York and London pp.,: 85-118.

Masola, B.M.; Chibi, Y.S.; Naik, E. and Zaranyika, M.F. (2003). Activities of glutamate dehydrogenase and aspartate and alanine aminotransferase in fresh water snails Helisoma duryi and Lymnaea natalensis exposed to copper. Biomarkers., 8(1): 33-42.

Mohamed, A.M.; El-Emam,M.A.; Osman,G.Y.; AbdelHamid,H. and Ali, R.A. (2012). Effect of Basudin, Selecron and the phytoalkaloid Colchicine (pesticides) on biological and molecular parameters of Biomphalaria alexandrina snails. Pesticide Biochemistry and Physiology., 102:68-78.

Morad, E.M.N. (2005). Comparative study on the molluscicidal activity of some plant extracts on snail vector of Schistosoma mansoni, Biomphalaria alexandrina. Ph. D. Thesis Fac. Sci. Cairo Univ., Egypt.

Ragheb, M.; El-Tayeb, T.A.; El-Emam, M.A.;* Amer, M. A. and Bashtar, A.M. (2018). Fecundity, sex hormones and release of cercariae of Schistosoma mansoni in Biomphalaria alexandrina (Ehrenberg, 1831) treated with copper and magnesium chlorophyllin. Folia Malacol., 26(1): 17-24.

Reitman, S. and Frankel, S. (1957). A colorimetric method for the determination of serum glutamic oxalacetic and glutamic pyruvic transaminases. Am J Clin. Pathol., 28:56-63.

Sarquis, O.; Pieri, O.S.and Dos, S.J. (1997) .Effects of Bayluscide WP 70 on the survival and water-leaving behaviour of Biomphalaria straminea, snail host of schistosomiasis in northeast Brazil. Mem Inst Oswaldo Cruz., 92:619-23.

Sokal, R.R. and Rohlf, F.J. (1995). Introduction to Biostatistics. W.H. Freeman and Co., San Francisco., pp: 271- 273.

Stefan, R.W. and Rex, T.M. (1998) Singlet molecular oxygen (O); A possible effectors of eukaryotic gene expression. Free. Radical. Biol. Med., 24: 15201534 .

Wagner, S. and Skripchenko, A. (2003). Investigation of photosensitizing dyes for pathogen reduction in red cell suspension. Biotech. Hitochem., 78: 171-177. 
Wang,W.; Mao, Q.; Yao, J .; Yang ,W.; Zhang ,Q.; Lu, W.; Deng,Z. and Duan,L. (2018). Discovery of the pyridylphenylureas as novel molluscicides against the invasive snail Biomphalaria straminea, intermediate host of Schistosoma mansoni. Parasites \& Vectors., 11:291.

WHO (1965). Molluscicide screening and evaluation. Bull. WHO, 33: S6581.

WHO (1993). The control of schistosomiasis, Technical Report Series Geneva Switz., $1-86$.

WHO (2014). Schistosomiasis. Fact sheet No 115.

WHO (2017). Schistosomiasis. Fact Sheet No. 115 updated in October 2017.

WHO (2020). Schistosomiasis World Health organization 2 March 2020.

Yapi, Y.G.; Briet,O.J.; Diabate, S.;Vounatsou, P.; Akodo, E.; Tanner, M . and Teuscher, T. (2005). Rice irrigation and schistosomiasis in Savannah and Forest area of Cote d'Ivoire. Acta Tropica., 93 (2): 201-211. 